REGARDS

SUR L'ECONOMIE ALLEMANDE

BULLETIN ECONOMIQUE DU CIRAC
Regards sur l'économie allemande

Bulletin économique du CIRAC

$86 \mid 2008$

Varia

\title{
Système économique et social
}

LAMPERT Heinz, BOSSERT Albrecht, Die Wirtschafts- und Sozialordnung der Bundesrepublik Deutschland im Rahmen der Europäischen Union

\section{OpenEdition}

Journals

Édition électronique

URL : http://journals.openedition.org/rea/767

DOI : $10.4000 /$ rea. 767

ISBN : 978-2-8218-0868-3

ISSN : 1965-0787

Éditeur

CIRAC

Édition imprimée

Date de publication : 1 mai 2008

ISSN : 1156-8992

Référence électronique

"Système économique et social », Regards sur l'économie allemande [En ligne], 86 | mai 2008,

document 9, mis en ligne le 14 mai 2008, consulté le 22 septembre 2020. URL : http://

journals.openedition.org/rea/767; DOI : https://doi.org/10.4000/rea.767

Ce document a été généré automatiquement le 22 septembre 2020.

(C) CIRAC 


\section{Système économique et social}

LAMPERT Heinz, BOSSERT Albrecht, Die Wirtschafts- und Sozialordnung der Bundesrepublik Deutschland im Rahmen der Europäischen Union

\section{RÉFÉRENCE}

LAMPERT Heinz, BOSSERT Albrecht, Die Wirtschafts- und Sozialordnung der Bundesrepublik Deutschland im Rahmen der Europäischen Union, Olzog Verlag, Munich, 2007, 456 p.

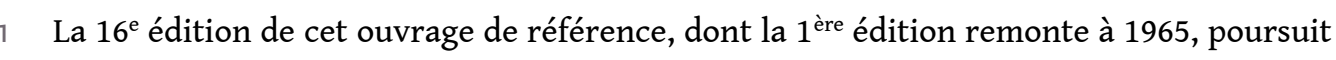
la rénovation de perspective entreprise par les auteurs depuis 2000 à la suite de la mise en place de l'UEM. L'analyse du système économique et social allemand qu'ils proposent prend désormais pleinement en compte les changements et les incidences que l'intégration européenne implique dans le gouvernement économique et social de l'Allemagne, notamment dans des domaines aussi importants que la politique conjoncturelle, la politique de la concurrence, le droit du travail ou la politique sociale. L'ouvrage met ainsi largement en évidence, à partir du cas allemand et exemples à l'appui, que les politiques nationales des Etats membres de l'UE ne peuvent plus être raisonnablement analysées en faisant abstraction du cadre et des politiques communautaires. (rl) 